\title{
Description of a new pseudoscorpion, Parolpium litoreum sp.n. (Pseudoscorpiones: Olpiidae) from southern Islands of Iran
}

\section{Описание нового вида можнноскорпионов Parolpium litoreum sp.n. (Pseudoscorpiones: Olpiidae) с южных островов Ирана}

\author{
Mahrad Nassirkhani ${ }^{1,3}$, Alireza Zamani ${ }^{2}$ \\ М. Нассирхани ${ }^{1,3}$, А. Замани \\ ${ }^{1}$ Entomology Department, Faculty of Agriculture and Natural Resources, Islamic Azad University, Arak branch, Arak, Iran.
${ }^{2}$ School of Biology, College of Sciences, University of Tehran, Tehran, Iran.
${ }^{3}$ Corresponding author. E-mail: greenartificialturfgrass@gmail.com
}

KEY WORDS: Arachnida, pseudoscorpions, fauna, taxonomy, Hormozgan, mangrove, Hormuz Island, Qeshm Island.

КЛЮЧЕВЫЕ СЛОВА: паукообразные, ложноскорпионы, фауна, таксономия, провинция Хормозган, мангровые заросли, остров Ормуз, остров Кешм.

ABSTRACT. The pseudoscorpion genus Parolpium Beier, 1931 (Olpiidae) is reported from Iran for the first time, and a new species, Parolpium litoreum sp.n. is described on the basis of two females collected in the littoral zone of the Persian Gulf in southern Iran. In addition, illustrations, measurements, and some notes on its habitat occurrence are given.

How to cite this article: Nassirkhani M., Zamani A. 2018. Description of a new pseudoscorpion, Parolpium litoreum sp.n. (Pseudoscorpiones: Olpiidae) from southern Islands of Iran // Arthropoda Selecta. Vol.27. No.4. P.325-329. doi: 10.15298/arthsel. 27.4.07

PЕЗЮМЕ. Род ложноскорпионов Parolpium Beier, 1931 (семейство Olpiidae) впервые отмечен в фауне Ирана, новый вид Parolpium litoreum sp.n. описан по двум самкам, собранным в литоральной зоне Персидского залива в южном Иране. Даны иллюстрации, промеры нового вида и некоторые сведения о его местообитании.

\section{Introduction}

The poorly studied pseudoscorpion genus Parolpium Beier, 1931 (family Olpiidae Banks, 1895) belonging to the subfamily Olpiinae Banks, 1895 currently contains only three species. These species are reported from Africa and southern Asia: Parolpium minor (Ellingsen, 1910) from Cape Verde, South Africa, and Uganda; Parolpium gracile (Beier, 1930) from Saudi Arabia, and Parolpium pallidum Beier, 1967 from India [Harvey, 2013].

Recently, a new species of the genus Parolpium was discovered in a small collection made on the southern coast of two small Iranian Islands. In this paper, the new species is described and illustrated based on two females, one collected from under a stone and one from under bark of a mangrove tree, Avicennia marina, known locally as the "hara" or "harra" tree. Both specimens were located in a wetland near the Persian Gulf. Some ecological features of the species are briefly discussed.

\section{Material and methods}

The specimens examined in this study were permanently mounted on cover-slipped on depression microscope slides in Swann's medium. The mounts were examined with an Olympus $\mathrm{CH}-2$ compound microscope and illustrated with a drawing tube attachment. Measurements were taken by a calibrated ocular micrometer. Morphological terminology and measurements follow Chamberlin [1931], Harvey [1992], Judson [2007] and Harvey et al. [2012]. The specimens used in this study are lodged in the collection of the Acarology Laboratory, Islamic Azad University of Arak (IAUA), Iran.

The following trichobothrial abbreviations were employed: $e b$ - external basal; esb - external subbasal; est - external sub-terminal; et - external terminal; $i b$ - internal basal; is $b$ - internal sub-basal; ist - internal sub-terminal; it - internal terminal; $t$ terminal; $s t$ - sub-terminal; $b$ - basal; $s b$ - subbasal. In addition, the following abbreviations are used in the text: L — length; W — width; D — depth; TS tactile seta.

Genus Parolpium Beier, 1931

Type species: Olpium gracile Beier, 1930, by original designation.

REMARKS. The newly collected specimens from Iran are attributed to the genus Parolpium belonging to the sub- 

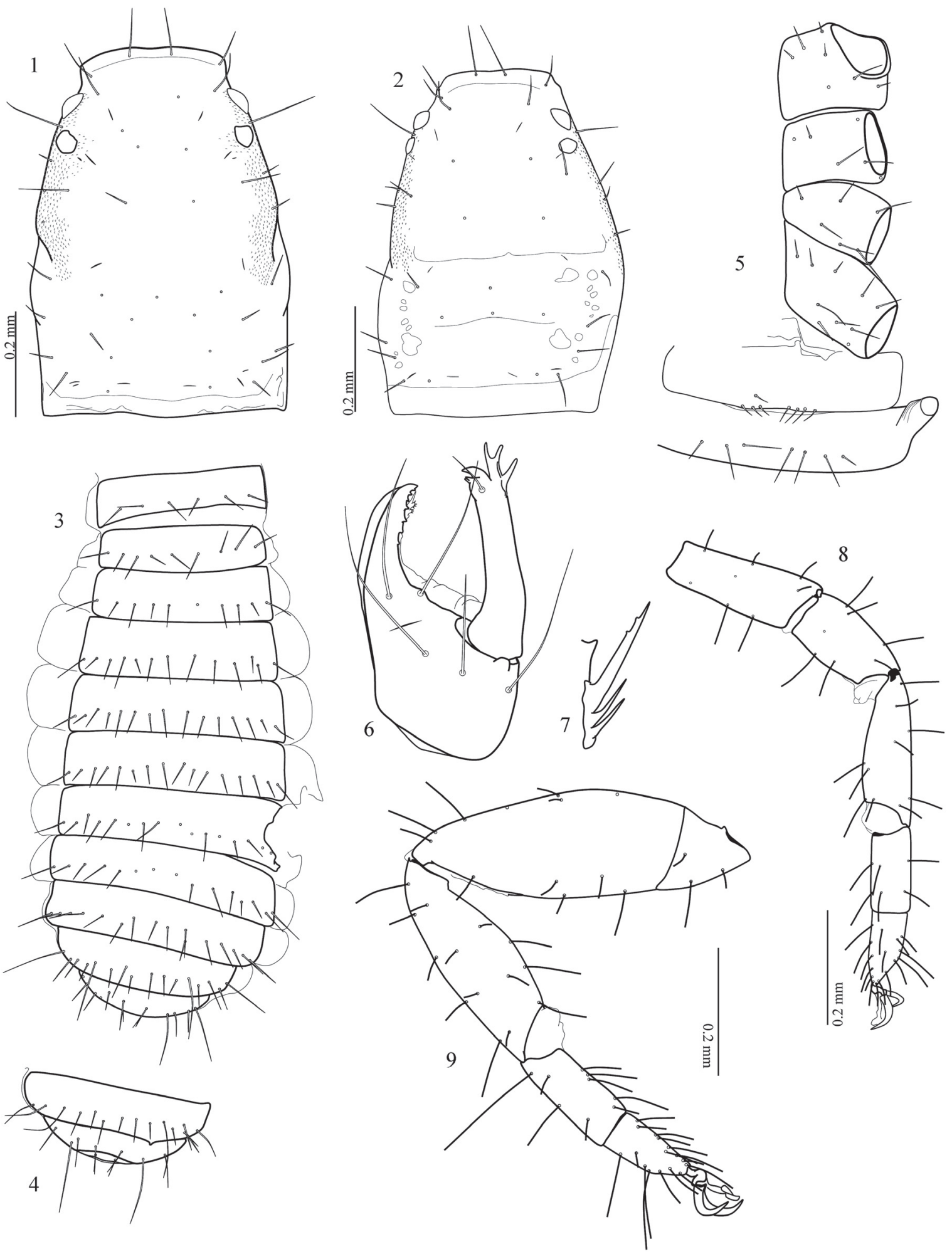

Fig. 1-9: Parolpium litoreum sp.n., holotype $+(1,3-9)$ and paratype + (2): 1, 2 - carapace, dorsal view; 3 - tergites, dorsal view (showing tergal chaetotaxy); 4 - sternites X-XII, ventral view (showing sternal chaetotaxy); 5 - left coxae and sternites II-III, ventral view; 6 - chelicera (serrula exterior omitted), ventral view; 7 - rallum; 8 - leg I, lateral view; 9 - leg IV, lateral view.

Рис. 1-9: Parolpium litoreum sp.n., голотип $q$ (1, 3-9) и паратип + (2): 1, 2 - карапакс, дорсально; 3 - тергиты, дорсально (показана хетотаксия); 4 - стерниты X-XII, вентрально (показана хетотаксия); 5 - левые тазики и стерниты II-III, вентрально; 6 хелицера (без серрулы), вентрально; 7 - раллум; 8 - нога I, вид сбоку; 9 - нога IV, вид сбоку. 
family Olpiinae because of the following distinctive characters: loss of distinct transverse furrows on the carapace, presence of 6-16 setae on tergites II-XI, trichobothrial pattern of the chelal fingers, e.g. the basal position of the ist (pattern contains $e b, e s b, i s b, i s t$, and isb on the basal third of the finger), and the length of aroliae being at least as long as the claws.

The only other genus of the subfamily Olpiinae is Stenolpium Beier, 1955 which was reported from Mangrove trees (in litter) of the Galapagos Islands, Eastern Pacific Ocean [Beier, 1978; Mahnert, 2014]. Members of this genus can be easily separated from the species of the genus $\mathrm{Pa}$ rolpium by the position of the trichobothrium ist which is located in the middle or distal half of the fixed chelal finger (pattern includes $e b, e s b, i s b$, and $i b$ on the basal third of the finger), and with the basal position of a long tactile setae on the pedipalpal femur.

\section{Parolpium litoreum sp.n.} Figs 1-12.

MATERIAL EXAMINED: IRAN: Hormozgan Province: Holotype + (IAUA), Hormuz Island, $27^{\circ} 03^{\prime} 10^{\prime \prime} \mathrm{N} 56^{\circ} 30^{\prime} 1.2^{\prime \prime} \mathrm{E}$, August 2017, under stone in supralittoral zone of the Persian Gulf, leg. F. Heidari. Paratype $q$ (IAUA): Hormozgan Province: Qeshm Island, $26^{\circ} 41^{\prime} 43^{\prime \prime} \mathrm{N} 55^{\circ} 37^{\prime} 06^{\prime \prime} \mathrm{E}$, date undetermined, under bark of Mangrove [Avicennia marina], littoral zone of the Persian Gulf, leg. N. Delfan

ETYMOLOGY. This species is named in recognition of the unusual environment occurrence for a member of this genus (litoreum, Latin, pertaining to littoral zone).

DIAGNOSIS. Parolpium litoreum sp.n. differs from the other species of the genus by the shape of the galea, e.g. with two apical and one basal rami, the median position of the trichobothrium est on the fixed chelal finger, and the pedipalpal granulation pattern, e.g. the mediodistal face of patella is granulated.

\section{DESCRIPTION. Females} $\mathrm{mm})$.

Body length: Holotype $-2.50 \mathrm{~mm}$ (paratype -2.62

Carapace: yellowish-brown to brown, slightly lighter in color than pedipalp, posterior margin pale and desclerotized; distal half of lateral margins finely granulate (Figs 12 ); one small protuberance located sub-basally on each side; 1.40-1.41 times longer than broad; with 2 pairs of welldeveloped, corneate eyes; anterior eyes located about one ocular diameter away from the anterior margin, larger than posterior eyes; transverse furrows absent (anterior transverse furrow slightly present in paratype); with total of 35 40 setae, each anterior and posterior margin with 4 setae, ocular area with 11-12 simple, thin and acute setae; with 10 lyrifissures (Figs 1-2).

Tergites: yellowish-brown; lightly sclerotized and entirely smooth; without median division; with acute, simple setae; IX with two slightly long lateral setae; X-XI with 4 long tactile setae located laterally and lateromedially (Fig. 3 ) chaetotaxy: 6:8-9:10:13-14:14-15:14-16:14-16:1415:15-16:T3T6T4T-T3T5T2T:T2T2T2T-T2T3T2T:2.

Sternites: pale yellowish-brown; slightly sclerotized; entirely smooth; without median division; genitalia with single median pear-shaped cribriform plate and a small and oviform lateral cribriform plate in each side; all setae simple, thin and many of them shorter than tergal setae; anterior operculum with 7 or 8 setae located on the border line of the genital aperture, median discal setae absent, posterior operculum with 7-9 setae situated away from genital aperture
(Fig. 5); IX with 2 slightly long setae located laterally; X-XI with 2 long lateromedian tactile setae (Fig. 4); base of tracheal trunks not inflated; chaetotaxy: 7-8:(0)7-9(0):(0)1112(0):13:13-15:13-14:15:12-16:2T6T5-4T6T3:1T3T12T4T2:2.

Pleural membrane: longitudinally striate.

Chelicera: yellowish-brown; galeal seta situated subdistally; galea with 2 apical and 1 basal rami (Fig. 6); hand with 5 simple setae (Fig. 6); rallum with 3 blades, anterior blade longer and wider with short lateral denticulations, posterior blades simple (Fig. 7); serrula exterior with 17-19 blades; serrula interior and lamina exterior present; fixed finger with 5-6 teeth, first two teeth acute and very small; movable finger with one apical lobe and two subapical teeth (Fig. 6).

Pedipalps: uniformly coloured, brown to reddish-brown, darker in color than carapace; retrolateral surface of trochanter, anterior half of femur, mediodistal surface of patella, and base of chelal fingers granulate (Fig. 10); both faces of chelal hand granulated (Figs 11-12); all setae simple and acute; trochanter with a small dorsal hump, L/W 1.81-2.12; femur with distinct pedicel, with 1 long tactile seta without enlarged alveoli located in the middle of the segment (Fig. 10), L/W 3.16-3.19; patella with 4 lyrifissures situated basally, L/W 2.34-2.47; chela (with pedicel) L/W 3.26-3.60; chela (without pedicel) L/W 3.03-3.28; hand (with pedicel) L/W 1.74-1.88; movable finger as long as hand (with pedicel); fixed finger with 8 and movable finger with 4 trichobothria (Figs 10-12); fixed finger with trichobothrium it situated closer to trichobothrium et than to est, est in the middle of the finger, $i s b$ on retrolateral face of the finger, $i s b, i b$, ist, esb and $e b$ aggregated basally; movable finger with trichobothrium $t$ situated at the same level as ist, st closer to $s b$ than to $t, s b$ at the same level as $i s b$; no short sensory seta located near trichobothrium $t$; prolateral face of fixed finger with a row of short sensory setae among teeth; 4-5 short sensory setae located on retrolateral face of the finger between trichobothrium et and tip of fixed finger; one short leaf-like seta located close to trichobothrium it (Figs 10-11); fixed finger with 39 blunt similar shaped and sized teeth; movable finger with 34-41 teeth, 18-22 distal teeth with obvious caps, these teeth reaching trichobothrium $t$, first apical pair of teeth small and acute, others blunt, 15-19 basal teeth becoming more flat along a row reaching trichobothrium $s b$ (Fig. 11); venom ducts very short; nodus ramosus situated distinctly close to tip of fingers (Figs 11-12).

Legs: yellow; smooth; all setae simple and acute; claws symmetrical, thin and elongate; arolia simple and as long as claws (Figs 8-9); chaetotaxy of coxae (Fig. 5): 4-7:4-6:6:810; all setae simple and acute; joint between femur and patella of legs III and IV as in Fig. 9; leg I (Fig. 8): femur L/ D 2.44-2.71; patella L/D 1.75-1.89; femur 1.29-1.35 times longer than patella; tibia L/D 3.50; metatarsus L/D 2.002.40; tarsus L/D 2.00-2.50; leg IV (Fig. 9): femur + patella L/D 3.19-3.54; tibia L/D 3.27-3.30; metatarsus with one tactile seta situated basally (TS=0.12), L/D 2.43-2.67, chaetotaxy: TS + 1/2/5; tarsus IV L/D 2.33-2.60.

Dimensions (in mm): 9 Carapace: 0.65-0.70/0.46-0.50. Pedipalp: trochanter 0.29-0.36/0.16-0.17; femur 0.51-0.60/ $0.16-0.19$; patella $0.47-0.54 / 0.19-0.23$; chela (with pedicel) $0.90-1.01 / 0.25-0.31$; chela (without pedicel) $0.82-0.94$; hand (with pedicel) L. 0.47-0.54; movable finger L. 0.47-0.54. Leg I: femur 0.19-0.22/0.07-0.09; patella $0.14-0.17 / 0.08-$ 0.09 ; tibia $0.21-0.28 / 0.06-0.08$; metatarsus $0.12-0.14 / 0.05-$ 0.07 ; tarsus $0.10-0.12 / 0.04-0.06$. Leg IV: femur $0.13-0.15$ / $0.08-0.12$; patella $0.37-0.42 / 0.13-0.16$; Femur + patella 

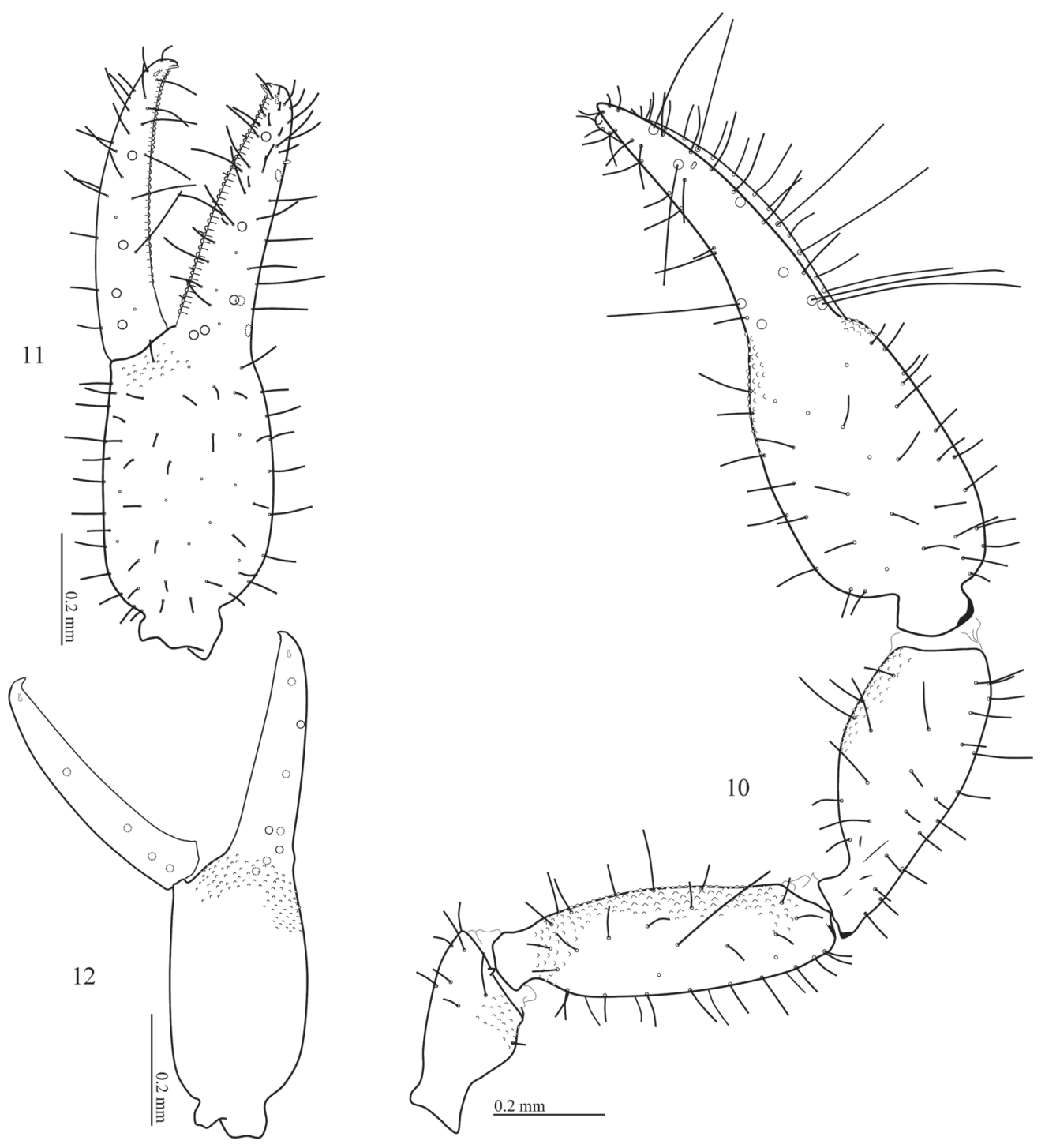

Fig. 10-12: Parolpium litoreum sp.n., holotype $+(10-11)$ and paratype $q$ (12): 10 - right pedipalp, dorsal view (showing granulation pattern and trichobothriotaxy); 11 - left chela, lateral view (showing trichobothriotaxy, teeth structure and granules on retrolateral face); 12 - left chela, lateral view (showing trichobothriotaxy and granules on prolateral face).

Рис. 10-12: Parolpium litoreum sp.n., голотип $+(10-11)$ и паратип + (12): 10 - правая педипальпа, дорсально (показан тип структура грануляции и трихоботриотаксия); 11 - левая хела, вид сбоку (показана трихоботриотаксия, структура зубов и гранулы на ретролатеральной стороне); 12 - левая хела, вид сбоку (показаны трихоботриотаксия и гранулы на пролатеральной стороне).

$0.46-0.51$; tibia $0.33-0.36 / 0.10-0.11$; metatarsus $0.16-0.17$ / 0.06-0.07; tarsus 0.13-0.14/0.05-0.06.

Males. Unknown

\section{Remarks}

On the basis of the galeal structure which is normally with three apical rami in Parolpium pallidum and Parolpium minor (in Beier, 1932, 1967), the newly collected specimens from Iran resemble Parolpium gracile which can be characterized by the galea with two apical rami and one basal ramus [Beier, 1930, 1932].
Parolpium litoreum sp.n. can be separated from $P$. gracile by the pedipalpal granulation pattern, e.g. the patella is granulated in $P$. litoreum, whereas it is entirely smooth in $P$. gracile, and the chelal hand is rather more granulated in $P$. gracile. The other observable differences are the trichobothriotaxy (trichobothrium est located proximal to middle of the fixed chelal finger in P. gracile (see Beier, 1930: fig. 4), while it is located at the middle of the fixed chelal finger in $P$. litoreum), and the tergal chaetotaxy (6:8-9:10:1314:14-15 in P. litoreum; 8:8:12:12:12 in P. gracile). The presence/absence of granules on the carapace, and the chaetotaxy of metatarsus IV were not described by 
Beier [1930, 1932] for P. gracile, so these characters can not be compared here and the types should to be reexamined for clarification.

\section{Distribution and ecology}

The family Olpiidae has been mostly found in xeric environments [Harvey, Leng, 2008]. Surprisingly, the holotype of $P$. litoreum sp.n. was found under a stone in the supralittoral zone of the Persian Gulf in Hormuz Island and the paratype was collected from under bark of a mangrove tree in the coastal saline waters of the Persian Gulf in Qeshm Island.

Mangrove trees are commonly found in tropical and subtropical tidal areas which are influenced by the cycling of the tides making a wetland between high and low tide marks and can be considered as a site of complex interactions between terrestrial and aquatic ecosystems.

This species is currently known only from the type localities in Hormozgan Province, southern Iran. Both specimens have been collected from aquatic regions. It is possible that this species has a wide range of distribution in similar habitats, across the Persian Gulf and the Gulf of Oman.

The occurrence of only two females in these tidal wetlands is not sufficient to characterize this species as a semi-aquatic pseudoscorpion, and only shows that it is capable of living and probably reproducing in areas with broad ranges of salinity, temperature, and humidity.

\section{Acknowledgments}

We are very grateful to Firoozeh Heidari and Nastaran Delfan for providing us with their collected specimens, Prof. James Cokendolpher kindly checked the English of the manuscript and provided us with useful comments and literature, and to Mr. Mahmoud Nassirkhani for his assistance.

\section{Disclosure Statement}

No potential conflict of interest was reported by the authors.

\section{References}

Beier M. 1930. Pseudoscorpione aus Marocco nebst einer Art von der Insel Senafir // Bulletin de la Société des Sciences Naturelles du Maroc. Vol.10. S.70-77.

Beier M. 1932. Pseudoscorpionidea I. Subord. Chthoniinea et Neobisiinea // Das Tierreich. Lfg.57. S.1-258.

Beier M. 1967. Pseudoscorpion vom kontinentalen Südost-Asien // Pacific Insects. Vol.9. No.2. S.341-369.

Beier M. 1978. Pseudoskorpione von den Galapagos-Inseln // Annalen des Naturhistorischen Museums in Wien. Bd.81. S,533547.

Chamberlin J.C. 1931. The arachnid order Chelonethida // Stanford University Publications, Biological Sciences. Vol.7. No.1. P.1-284.

Harvey M.S. 1992. The phylogeny and classification of the Pseudoscorpionida (Chelicerata: Arachnida) // Invertebrate Taxonomy. Vol.6. P.1373-1435.

Harvey M.S. 2013. Pseudoscorpions of the world, version 3.00. Western Australian Museum. http://museum.wa.gov.au/catalogues-beta/pseudoscorpions [accessed 6 august 2018].

Harvey M.S., Leng M.C. 2008. The first troglomorphic pseudoscorpion of the family Olpiidae (Pseudoscorpiones), with remarks on the composition of the family // Records of the Western Australian Museum. Vol.24. P.387-394.

Harvey M.S., Ratnaweera P.B., Randeniya P.V., Wijesinghe M.R. 2012. A new species of the pseudoscorpion genus Megachernes (Pseudoscorpiones: Chernetidae) associated with a threatened Sri Lankan rainforest rodent, with a review of host associations of Megachernes // Journal of Natural History. Vol.46. P. 2519-2535.

Judson M.L.I. 2007. A new and endangered species of the pseudoscorpion genus Lagynochthonius from a cave in Vietnam, with notes on chelal morphology and the composition of the Tyrannochthoniini (Arachnida, Chelonethi, Chthoniidae) // Zootaxa. Vol.1627. P.53-68.

Mahnert V. 2014. Pseudoscorpions (Arachnida: Pseudoscorpiones) from the Galapagos Islands (Ecuador) // Revue suisse de Zoologie. T.121. Fasc.2. P.135-210.

Responsible editor K.G. Mikhailov 